\title{
A Study of Feudal Coalition and Control System in Tokugawa Japan
}

\author{
Ajoy Kumar Das \\ Department of Japanese, Visva-Bharati, Santiniketan, West Bengal, India
}

Corresponding author: daskumarajoy@gmail.com

Received: 02-10-2020

Revised: 19-11-2020

Accepted: 02-12-2020

\begin{abstract}
This article is about political scenario of early Edo period and successfully controlling over feudal coalition of local lords and various control measures of Tokugawa system. Beginning with the Onin War, Japan slipped into the century of sporadic civil war known as Sengokujidai or Warring State period in which local feudal lords (daimyo) ignored the shogunate and the imperial court and struggled with each other for local hegemony. From the mid-16 ${ }^{\text {th }}$ century, a movement towards national reunification gradually emerged out of the violence of the warring feudal domains and was carried through by three powerful hegemons, and they were successful in controlling the feudal coalition. The main objective of this paper is to investigate the effective role and policies of Tokugawa system. This paper focuses how the feudal coalition was controlled and features of control measures adopted by Tokugawa Japan and effectively maintained the political status quo, but at the same time they promoted economic changes that slowly undermined the Tokugawa order.
\end{abstract}

Keywords: Tokugawa period, Samurai, Feudal coalition, Daimyo, Local power, Castle, Bakufu, Oda Nobunaga, Toyotomi Hideyoshi, Tokugawa Ieyasu, Shogun, Shogunate, Han

Before Tokugawa period (1603-1868), when the first Europeans arrived, Japan was in the midst of a fullblown feudal period, marked by continuous widespread warfare. During the warring states period, 1467-1568, power was fragmented to an extraordinary degree. Not only had the authority of the central government dissolved but regional power holders too had lost their positions. Power, is short, lay at the local level. The most important institution was the small feudal state dominated by local lord and his band of warriors known as samurai. The lord's power was based on his own military strength, for there were no sources of security and prestige other than raw power. His position depended on the continuing loyalty of his samurai retainers, and thus he rewarded his leading vassals with fiefs and titles.
The normal state of relations among these small feudal states was warfare. This was a period of great instability, and fluctuations in power and in amounts of territory controlled were continuous. If a lord failed to defend his territory he would either lost it to a more powerful neighboring lord or he would be overthrown by one of his own vassals. Perhaps because betrayal and treachery were frequent, loyalty was the highest virtue. Yet no lord could wholly trust his vassals, they might try to overthrow him, or if they felt he was losing to a neighboring lord they might break away and join that lord.

How to cite this article: Das, A.K. (2020). A Study of Feudal Coalition and Control System in Tokugawa Japan. Int. J. Soc. Sci., 9(04): 307-311.

Source of Support: None; Conflict of Interest: None (c) 9 
In these conditions of endemic warfare, lords were constantly suspicious of one another. It was not just that they were power mad, but rather, somewhat like nations in modern times, each one was afraid of his neighbor, fearful that if he himself did not expand, he would be conquered. The overriding concern of each lord, therefore, was to maximize his military power. Power could scarcely have been further fragmented. Gradually, however, stabilizing forces began to appear. To overcome the conditions of upheaval and instability new institutions were created in the late fifteenth century, culminating in the establishment of the Tokugawa hegemony and the reunification of the country.

\section{Establishment of Local Power and Castle}

The foundation for this great new unified order was laid in the second half of the sixteenth century with the consolidation of power at the local level. The primary reason for the new stability was the emergence, after a century of warfare, of feudal lords or daimyo, throughout the century who were able to impose greater control than their predecessors had over both their fighting men and economic resources of the territory they controlled. The local lord gained greater power vis-à-vis his samurai retainers by gradually diminishing the independent power bases that had existed within his domain. He learned that by obliging his vassals to reside close to him he could much more effectively control them. The lord achieved greater subordination of his warrior by organizing them more tightly into a methodical ranking. Similarly he was finding more systematic ways to assess the land tax on the peasantry in his domain. In this way the daimyo formed regional groupings led by a particularly powerful lord.

This consolidation of power at the local level and the increased strength of daimyo were dramatically symbolized by the massive castles they built in the latter half of the sixteenth century. In a relatively short space of time castles sprang up across the Japanese countryside. In all parts of the country the newly emergent daimyo, who numbered over two hundred, built great stone fortress at the heart of their domain, where they could assemble their samurai retainers and effectively dominate the strategic and productive resources of the surrounding countryside. These central citadels with towers soaring above the landscape symbolized the new ascendancy of the daimyo at the local level.

To build the great structures they had to be able to mobilize large amounts of labor and to assemble highly skilled craftsmen. Previously, during the Warring State Period, fortifications had been of much smaller proportions and were ordinarily located on mountain tops, but in the new, more stable conditions castles were built in the lowlands and plains. Here, in and about the confines of the citadel, the lord settled his vassals and retainers. As the warriors move from the countryside into the castles, merchants and artisans and shrines and temples followed quickly to service the warriors' needs. Across Japan new "castle towns" came into being. Famous castles towns such as Himeiji, Osaka, Kanagawa, Wakayama. Tokushima, Kochi, Takamatsu, Hiroshima, Edo, Wakamatsu, Okayama, Kofu, Fushimi, Takasaki, Sendai, Fukuoka, Fukui, Kumamoto, Tottori, Matsuyama, Hikone, Fukushima, Yonezawa, Shizuoka, and Nagoya were founded during this time.

Prior to 1550 nearly everyone had lived in farming and fishing villages. There were only two or three population centers could accurately be called cities. One was Kyoto, the capital, which had about a quarter of a million inhabitants. Another was the nearby port of Sakai, the beneficiary of a flourishing overseas trade. Edo was still a fishing village. Castle towns become important urban centers in the various regions of Japan and remain so today. Edo grew into the modern metropolis of Tokyo. Two third of the present prefectural capitals were once castle towns. The building of those castle towns and the events associated with it, particularly the removal of most samurai from the countryside into the city, constitute one of the most important developments in the history of Japan.

At the same time he carried out his so-called "sword hunt" by an edict that forbade all non-samurai to keep swords, sidearm, daggers, spears or any other military equipment. Thus a sharp line of distinction was drawn between the sword-carrying warrior elite and the disarmed commoners. Toyotomo's purpose was to eliminate both physical and occupational mobility 
and to stabilize the social order. Thus, as the coalition of daimyo led by Toyotomi gradually brought the country under its authority, reforms were instituted that strengthened the daimyo vis-à-vis their retainers and that diminished the possibility of disruption at the local level. The basis was laid for the remarkable national social and political order that would endure over two and half century.

\section{Unification of Tokugawa Bakufu}

The stabilization of power at the local level made available the firm based upon which first regional and then national unity could be built. Gradually daimyo at the regional level joined together, the lesser daimyo pledging loyalty to or being conquered by the strongest daimyo in the region. It was three successive daimyo from central Honshu who assembled a powerful coalition of forces, one by one gained the submission of other regional clusters of daimyo, and ultimately succeeded in unifying Japan. These three lords were Oda Nobunaga (1534-1582), the son of a minor daimyo based in Owari province, his chief vassal Toyotomi Hideyoshi (1536-1598), born of humble parentage, the son of a foot soldier in the service of the Oda family and Toyotomis' vassal Tokugawa Ieyashu (1542-1616) became the first shogun of the Tokugawa shogunate.

They were successful to bring about a new centralization of power was due to (1) their strategic location in central Honshu, where they could control the greatest foodproducing plains in japan and where they had easy access to Kyoto, the capital and traditional symbol of legitimacy for national political power, (2) result of brilliant military mastery strategy. No less important, however, was their demonstrated mastery of two of the main sources of feudal power that had to be controlled and exploited: land and peasants.

Toyotomi Hideyoshi, who succeeded to leadership of the reunification campaign after Oda's death, was particularly successful in devising measures to strengthen control of the land and peasants under his sway. He was ordered a sweeping resurvey of the cultivated land in the countryside to determine the productivity of each price of land and identify the individual responsible for paying the tax on it. Not only did the land survey tighten collection of the land tax and provide a solid new basis for village for organization; in addition it allowed Toyotomi to assign to his vassal daimyo lands he conquered with firm knowledge of value of those lands.

After the death of Toyotomi Hideyoshi, the coalition of daimyo forces led by Tokugawa Ieyashu triumphed over an alliance of daimyo from western Japan. He emerged in a preeminent position, able to dispose of all those daimyo who would not accept his over lordship and possession of an immense amount of territory acquired as the spoil of war, which he could divide among his loyal followers. From this position of strength the Tokugawa family spent the next several decades building a new system of government. In 1603, Tokugawa Ieyashu was invested by the emperor with the position of shogun, traditionally the highest military office in the land of Japan.

The reality of Tokugawa power depended on stabilizing the coalition of daimyo through which national unification had been achieved. Ieyasu established his seat of government in Edo, where his new castle was built. Government by shogun, often referred to as the shogunate or bakufu, was an extremely complex and intricate mechanism. Basically the shogun administered the country along two lines.

First, roughly one-quarter of land belonged directly to the Tokugawa family, amassed during their rise to power. These lands scattered throughout the countryside but mostly concentrated in central Honshu, the Tokugawa administered directly through their own samurai retainers. In this category of direct Tokugawa rule were all the important mines, the major seaports, including Osaka and Nagashaki, and the old capital city Kyoto. Within these direct holdings the bakufu raised its funds, and its rule was in every way absolute.

Second, the reminder of the country, approximately three-quarters of it, was governed indirectly through the daimyo, all of whom after 1600 swore allegiance to the Tokugawa. It was this second, indirect mechanism of governing the country that gave the Tokugawa their greatest concern. Here their power was by no means absolute; it depended on maintaining the coalition of 
daimyo. Among the daimyo there were some who were very powerful, and the possibility of an anti-Tokugawa alliance among them was an ever-present danger.

During the two and a half centuries of Tokugawa rule, the number of daimyo varied between 240 to 295. A daimyo was officially defined as a lord possessing a han(domain) with an assessed productivity of at least 10,000 koku of rice ( $1 \mathrm{koku}=4.96$ bushels). The size of daimyo domains varied considerably; the largest was assessed at over a million koku. There were three different categories of daimyo:

1. The shimpan (related) daimyo were members of Tokugawa branch families. They were the closest to the head of the House of Tokugawa, descended by birth or adoption from Ieyasu. Should the mainline of the family die out, a shogun would be chosen from among these lords, who came to number 23. Assured of their absolute loyalty, the shogunate assigned the cadet house to domains in the Kanto region or at strategically important locations.

2. The fudai (hereditary) daimyo were those who had pledged loyalty to the Tokugawa prior to the decisive battle of Sekigahara in 1600 . They attained the rank under Tokugawa patronage and who, for the most part, had taken the field with Ieyasu at Sekigahara. Because their loyalty preceded this decisive battle, they were generally considered trustworthy and they helped staff the central councils of the shogunate.

3. The tozama (outer) daimyo were those who had taken Tokugawa Ieyasu as their overlord only after the battle of Sekigahara. Because their pledge of loyalty was relatively recent, they were generally regarded as less trustworthy and therefore excluded from positions in the shogunate. Indeed among the outer daimyo were lords who had fought against the Tokugawa coalition at Sekigahara, the two most important of which were the domains of Satsuma and Choshu.

\section{Tokugawa Control System}

To maintain hegemony over this unwieldy feudal coalition, the Tokugawa depended on various measures:
1. Rearrangement of domains. One of the most important control measures was the power the shogun had to rearrange or reassign landed holdings for strategic reasons. In this way the disposition of fiefs could be arranged so that potentially disloyal domain would be shunted to remote positions or hedged in by loyal daimyo.

2. Alternate attendancesystem. By far the mostimportant method devised for controlling the daimyo was what was called the system of alternate attendance. Under this system all daimyo were obliged to alternate their residence periodically between their domains and Edo. Ordinarily this meant residing in Edo every other year. While they were in Edo, the shogunate could maintain surveillance over them. When they returned to their domains, the daimyo were required to leave behind their wives and children as hostages.

3. The system also served as a continuous drain on the economic resources of the daimyo. They had to build and maintain house in Edo for their families and retainers, a considerable number of whom accompanied them on their biennial trip. While in Edo the daimyo were required to perform certain types of ceremonies as well as guard duty. The bakufu made periodic levies for money and labor. Sometime a daimyo was instructed to repair a castle, a shrine, or a bridge also. It became common for daimyo to spend over half of their domains' tax income for the costs of the alternate attendance system.

4. Seclusion. A third measure designed in part to control the daimyo was the isolation of Japan. This policy was designated to cut off the lords -- particularly the powerful outer lords-- from the military and economic sources of strength that foreign trade might offer them. It was also intended to eliminate Christianity as a source of social disruption in the stable order of Tokugawa were try to establish. For the most part, however, during the next two centuries Japanese society developed in almost complete isolation.

5. Ideology. A fourth control directed primarily at the daimyo and their retainers was the use of ideology. 
A Study of Feudal Coalition and Control System in Tokugawa Japan $\underset{\text { AESSRA }}{\sqrt[S]{S}}$

Neo-Confucian doctrines were given official sanction by the shogunate as a means of providing a philosophical foundation for the new social and political order taking shape. Confucianism was not new in Japan. It had been introduced centuries earlier but it had never been so appropriate as it now become. Confucianism held up familial relations as a proper model for government, relations between parents and child being analogous to those between ruler and subject.

In addition to the above controls, various measures were taken to regulate the activities of the daimyo. Many of them were codified. These directives regulated contracts between daimyo, the contracting of marriages between daimyo families, the repair of castles, and the like. Barriers were established on the main highways to monitor the comings and goings of daimyo and their retainers. A system of passports provided further means to check on travel.

\section{CONCLUSION}

We can conclude that the reality of Tokugawa power depended on stabilizing the coalition of daimyo through which national unification had been achieved. Tokugawa Ieyasu established his seat of government in Edo, where his new castle was built. Government by shogun, often referred to as the shogunate or bakufu, was an extremely complex and intricate mechanism. Basically the shogun administered the country and created a new and vastly more powerful kind of tent government than had existed in the past. The very success of Tokugawa system was in the long run responsible for its undoing. The roots of revolutionary economic and social change lay in the very reforms and various measures of Tokugawa system discussed, which were carried out in the sixteenth and seventeenth centuries to try to stabilize society.
The control measures, especially the alternate attendance system and removal of samurai from the countryside, effectively maintained the political status quo, but at the same time they promoted economic changes that slowly undermined the Tokugawa order. It is cleared that Ieyasue emerged in a preeminent position, able to dispose of all those daimyo who would not accept his over lordship and possession of an immense amount of territory acquired as the spoil of war, which he could divide among his loyal followers. From this position of strength the Tokugawa family spent the next several decades building a new system of government.

\section{REFERENCES}

Bix, Herbert P. 1986. Peasant Protest in Japan, 1590-1884. New Heaven: Yale University press.

Dore, Ronald P. 1965. Education in Tokugawa Japan. Berkeley: University of California Press.

Harold, B. 1974. Treasures among Men: The Fudai Daimyo in Tokugawa Japan. New Heaven: Yale University Press.

Harootunian, Harry D. 1988. Things seen and Unseen: Discourse and ideology in Tokugawa Nativism. Chikago: University of Chikago Press.

Jannetta, Ann Brown. 1987. Epidemics and Morality in Early Modern Japan. Princeto : Princeton University Press.

Michael, C. 1965. They came to Japan: An Anthology of European Reports on Japan, 1543-1640. Berkeley: University of California Press.

Smith, R.J. 1983. Japanese Society. Cambridge University Press, Cambridge. 
